\title{
Building Bridges: The Third Sector Responding Locally to Diversity
}

\section{By Margaret Harris and Patricia Young}

A Paper prepared for submission to the journal 'Voluntary Sector Review', September 2009. Revised following acceptance, November 2009. Will appear in the journal in March 2010.

Word length: 8114 including abstract, tables and references

Contact person for this paper:

Margaret Harris, Ph.D

Professor Emeritus Aston University and

Visiting Professor, Birkbeck, University of London

42 Meadway, London, NW11 6PR

Tel. 07860907779

Email m.e.harris@aston.ac.uk 


\title{
Building Bridges: The Third Sector Responding Locally to Diversity
}

\begin{abstract}
This paper focuses on a hitherto unstudied segment of the broad 'third sector': organizations and groupings which aim to build bridges (that is, increase inter-personal contacts) between people of different faiths and/or ethnic group. We draw on the findings of an empirical study, conducted in three diverse urban areas of England, of communitylevel projects with bridge-building as an explicit aim. We describe the characteristics of BBAs ('bridge-building activities') and the challenges they face; both the organisational challenges and those which arise from the nature of bridge-building itself. We conclude by exploring the implications of our findings for understanding of the third sector generally and for the potential role of the sector in responding to our diverse society.
\end{abstract}

\section{Introduction}

As the study of the voluntary or third 'sector' has developed and matured, there has been growing recognition of its internal heterogeneity (Harris et al., 2001; Kendall, 2003). Studies of the sector's organisations and groupings now frequently focus on 'subsectors'; areas of third sector activity distinguished according to variables such as organisational form and size, funding sources and types, members and participants, founding purpose, geographical level of action and types of activities or services. Thus third sector researchers have conducted studies focused on BME organisations, faithbased organisations, small and community organisations, self-help groups and third sector infrastructure organisations.

Such studies of 'sub-sectors' have not only contributed knowledge to other specialist fields such as policy implementation, organisational behaviour, community studies, social welfare and philanthropy, they have also help build a fuller picture of the third sector - with all its internal diversity. This paper follows in this tradition and contributes to the field of voluntary sector studies by focusing on a hitherto rarely-studied segment of the third sector: organizations, projects and groupings which aim to build bridges (that is, increase inter-personal contacts) between people of different faiths and ethnic groups at the local level where they live and work. We refer to them here as 'bridge-building activities' or 'BBAs' (1).

In addition to wanting to contribute to the field of voluntary sector studies by filling a gap in knowledge about a particular 'sub-sector', we were driven by two further research considerations. First there are a number of aspects of the current UK public policy environment which point to the importance of local connections across identity-group boundaries within an increasingly diverse society (DCLG,2006; Denham, 2002;). Earlier policies of encouraging respect for difference (often referred to as 'multiculturalism' - see Modood, 2007) are now regarded as needing to be complemented by policies which encourage social and community 'cohesion' (Cantle, 2001; Gilchrist, 2004); that is, interaction and mutual accommodation across the boundaries of identity groupings, emphasising commonalities as well as differences. There has been a particular emphasis on increasing inter-personal contacts between people of different faiths and 
ethnic groups and on encouraging them to develop shared values and achieve common goals (CIC, 2007; Faulkner, 2004). Yet activities which cross identity group boundaries at the 'grassroots' level have been given little research attention; even though public policies assume their existence (Flint and Robinson, 2008; Pennant, 2005). We therefore thought it timely to explore the nature of the bridging activities actually taking place under third sector auspices at the local level and to explore the extent to which BBAs have the potential to contribute to the implementation of public policy goals on social and community cohesion.

A further, related, consideration was our interest as voluntary sector researchers in exploring how civil society can be strengthened. Civil unrest is often associated with economic and social separation between ethnic and faith groups and competition for scarce public resources such as social housing, grants from governmental agencies and education and employment opportunities. Such separation and competition breeds low trust of 'the other' so that there is then little appetite for activities which foster interaction across identity group boundaries (Dench et al, 2006; Putnam, 2007). In this way, tendencies to separation and competition between ethnic and faith groups can be selfreinforcing and antithetical to building civil societies. More positively, however, research also suggests that inter-personal contact between members of different ethnic and faith groups can reduce inter-group hostility and prejudice (Allport, 1954; Jeong and Lerch, 1999). Thus third sector activities which facilitate and nurture interpersonal connections across faith and ethnic group boundaries may provide an important means for mediating cultural pluralism, mobilising social capital, and developing robust civil societies (Allen and Cars, 2001; Forrrest and Kearns, 2001; Furbey et al, 2006).

Although there is a clear policy expectation in the UK that local level third sector activities will contribute (albeit in ways largely unspecified) to building a cohesive and civil society and although several authors have identified geographical local communities as a key locus for interaction across identity group boundaries (eg Daley, 2009; Milligan and Fyfe, 2004; Weller, 2009) little research has been conducted into the ways in which links are nurtured at the local level between religiously and / or ethnically diverse groupings. In this paper, then, we explore the nature of local BBAs with a view to filling a gap in knowledge about this segment of the third sector and the contribution that BBAs might make to implementing UK public policy and supporting civil society development. We draw on the findings of an empirical study of community-level projects with bridgebuilding as a specific aim in three urban areas in England, each with a diverse ethnic and faith composition: the London Borough of Tower Hamlets (population according to the 2001 Census, 196,100); the City of Birmingham (2001 population 977,000); and the Borough of Oldham (2001 population 217,000). 


\section{The BBA Study}

The main purpose of our study was to discover the organisational features and challenges of third sector activities which aim to build bridges at the local level across the boundaries of ethnic and/or faith groupings. The empirical phase of the study took place in three stages. Stage One involved identifying and mapping local BBAs in the three study areas. In the absence of relevant data bases, we used networking and 'snowballing' methods, starting by contacting people who might be expected to be aware of such local level activities. Eventually we were able to identify 160 local BBAs across the three areas.

At Stage Two, each of the 160 BBAs was invited to nominate a leading member of their group to participate in a structured telephone interview intended to gather data about organisational features including: aims and objectives; history; focus (inter-ethnic / interfaith / both / other types of bridge building); activities (type, frequency, location and management); formal status (eg project, independent community association); and funding. Interviews were successfully completed with 127 BBAs; 37 in Tower Hamlets; 48 in Birmingham; and 42 in Oldham. Interviewees included founders, employees and volunteers. The data obtained from these 'key informants' was analysed quantitatively using SPSS (Harris and Young, 2009a; 2009b)

Stage Three comprised nine case studies, three conducted in each of the three study areas. These were intended to explore organisational features of BBAs in more depth and to obtain qualitative data about the range of approaches and the challenges of local bridge building as perceived by the key actors involved (Bryman, 2001). The nine cases were chosen from the 127 telephone respondents and were selected using 'theoretical sampling' (Eisenhardt, 1989); that is, they differed with respect to variables which earlier literature suggested could have implications for the work and challenges of local BBAs; including the target identity groups; activities; history; frequency of activities; and resources. The basic features of the nine case BBAs are shown in Table One. For each case we conducted face to face interviews and observed at least one group activity.

After initial analysis of the data from the nine cases, and following principles of action research (Cairns et al, 2007), we returned, as we had originally undertaken to do when negotiating access, to each of the case BBAs for feedback meetings with those originally interviewed. Most of the nine BBAs used the opportunity of our return visit to draw together their volunteers, members and trustees for an open discussion, in which we participated, about of the challenges they face and how to tackle them.

In the following two sections, we draw on data from all stages of the study to describe the bridging activities we found to be taking place in the three study areas, focusing on the organisational features of BBAs and the challenges they face in their work. We refer to people interviewed at Stage Three as 'study participants'. Quotations from them are shown in italics, along with a notation which refers to their BBA in Table One. (Thus interviewees from the three Birmingham BBAs are tagged as B1, B2, or B3 and so on.)

[Table One about here] 


\section{Organisational Features of Local BBAs}

\section{Founding}

Nearly $40 \%$ of the 127 BBAs interviewed were well established at the time of the study in 2007 , having started in 2002 or before that. The majority of respondents $(64 \%)$ said that their BBA was initially driven by a specific vision to build bridges across ethnic and/or faith groups. (The actual term 'bridge-building' was in common use in many of the BBAs and where it was not, it was widely recognised as a metaphor for the activities taking place.) Of the BBAs which did not begin with a specific bridge-building vision, most began with the aim of responding to perceived local needs.

For some groups, the initial emphasis was on creating community cohesion: "we wanted to get the various communities to work in harmony, to live in harmony and to develop our communities together" (B2). Other BBAs were more concerned with conflict avoidance: "the initial aim was to bring together people from the region; they were divided because of conflict. Our worry was not to let the parents transfer their hatred to their children" (B3).

More than one third (35\%) of the 127 began with a pre-existing third sector organisation expanding its range of activities or extending an existing project to include bridge building. An additional $27 \%$ began from an initiative taken by a governmental organisation or, more usually, a third sector organisation. Thus about $63 \%$ of all BBAs were originally nurtured by a pre-existing organisation. Twenty one per cent, on the other hand, reported that their BBA was started on the initiative of a lone entrepreneurial individual.

Even when BBAs were initially formed within a pre-existing organisational framework, it was often the case that just one or two highly committed and entrepreneurial 'founders' were the driving force behind the start. Such founders mostly came from professional backgrounds (eg they were teachers or clergy) but were also 'rooted' in the local area through long residence, work association, and/or membership of a particular local identity group. Many of these founders had special experiences in their personal lives of crossing ethnic or faith boundaries, for example of growing up in an ethnically- or faith- mixed household or a diverse neighbourhood. Such people seemed to be exceptionally skilled at relating to a range of different people and, additionally, at encouraging interpersonal networking between them.

\section{$\underline{\text { Aims of BBAs }}$}

Our telephone survey only included representatives of BBAs which were explicitly aiming to bring together people across ethnic and/or faith boundaries. Within that broad aim, we examined the formally stated aims of BBAs and gave respondents the opportunity to tell us about as many as they wished. Most BBAs had two or more formal aims. The most often-cited were those involving the development of social cohesion and social integration ( $90 \%$ of BBAs surveyed), and social contact and social interaction $(86 \%$ of all BBAs). Eighty per cent of respondents mentioned an aim of mutual learning or mutual understanding and $76 \%$ referred to community development aims. More practical and tangible aims such as physical regeneration and crime reduction were less often mentioned. All except 6 of the 127 respondents gave one or more of the first three categories as a formal aim; that is, $95 \%$ of all the local BBAs we interviewed were aiming 
at social cohesion and/or social interaction and/or mutual understanding.

\section{Identity Groups involved in BBAs}

The responses to a question to respondents at Stage Two about the groups they targeted in their bridge building activities are shown in Table Two. They reflect earlier research which has argued that ethnicity and faith are categorisations which do not necessarily match personal experience of group boundaries or the difficulties in practice of clear categorisation by faith or ethnicity (Amin, 2002; Malek, 2008; Modood, 2007). Thus only $61 \%$ stated that their BBA was mainly about what was clearly 'inter-ethnic' or 'inter-faith' relationships; for example "bringing together black, Asian and white men" or "working with the Muslim, Christian and Hindu communities". The remainder described the groupings that they sought to bring together in a variety of ways and in a variety of combinations.

\section{[Table Two about here]}

A total of 25 (19\%) of BBAs were either solely concerned with bridging between people from different countries of origin or partially concerned with it. This finding is a reminder that differences in national or country cultures can be as much a source of hostility and low trust as can be faith or ethnicity as such. Moreover a common religion does not necessarily tie people together if they come from different country or regional cultures.

\section{Approaches to Bridge-Building}

We again used a multiple response question when we asked at Stage Two about the specific activities sponsored by BBAs (Table Three) as we were keen to explore the full range of activities encompassed under the 'bridge-building' umbrella term. The most frequently mentioned activities were social ( $81 \%$ of all BBAs surveyed); education, training and learning activities (72\%); and facilitated dialogue (64\%) (2). In fact, only four of the 127 respondents did not mention at least one of these activities; and 54 (43\%) mentioned all three. These findings about the popularity of social, educational and dialogue activities are in line with earlier literature in which these three kinds of activities are recorded as widely used in efforts to increase inter-group contacts or achieve conciliation between antagonistic groupings (Amin, 2002: Gilchrist, 2004). The next two most frequently cited activities were sport and visual arts. Sport, especially football, is, it seems, a popular way of bringing together boys and young men. Although some literature suggests that it is important to address sources of conflict directly (eg Barekh, 2000 ) references to faith-based activities and conflict resolution were low (32\% and $23 \%$ respectively).

\section{[Table Three about here]}

The case studies at Stage Three helped to explain the choice of activities and approaches used by BBAs. The popularity of educational activities seemed to be largely attributable to the availability of governmental funding for such activities. In fact, education and training were identified by study participants as two of the very few activities for which they could obtain funding relatively easily. In contrast, external funding for social activities was very difficult to obtain - although social activities were highly popular as a means to build bridges. This was partly for negative reasons; it had been found that potential participants were more likely to be attracted to informal 
activities which did not demand much initial commitment. More positively, social activities were seen as a good means of preparing people for more intensive bridgebuilding - by breaking down barriers and showing people that they could be with different people without harm. Similarly, it had been found that just interacting socially while engaged on a common task, such as a planning a fete or an arts event, could become a "wonderful vehicle for exploring differences and commonalities ... change people, make them think different, make them more open" $(\mathrm{O} 2)$. In practice it had been found that simple social interactions and work on a common task could gradually lay a foundation for more ambitious forms of bridge-building. For example, social activities in which food was shared between Muslims and Christians was described as having helped to build "relationships of trust and friendship" which eventually led to plans to build a shared place of worship, which "would enable a real permeability between the two worshipping traditions" (T1).

The third most mentioned approach to bridge building - facilitated dialogue - was implemented in a variety of ways and given various rationales. It was described by one study participant as "giving people a platform to ... say what they really think" $(\mathrm{O} 1)$. It was felt that only by creating the space for people to be open in expressing their views, would it be possible to find strategies to overcome negative perceptions of other communities. In contrast with this confrontational approach, another study participant described interfaith dialogue undertaken in a low key and respectful way to "explore where are the mutually comfortable boundaries. You need to know how you are different as well as how you are the same" (T1). For example, members of a Christian congregation were invited to attend Iftar (the Muslim break-fast at sunset during Ramadan), during which the role of fasting in both religions was discussed.

Data collected at Stage Three suggested that, irrespective of the activities which were favoured by BBAs, broad 'community development' and community 'capacity building' approaches underpinned much BBA activity. This approach was "about giving people a repertoire of skills which they can deploy within their communities" $(\mathrm{O} 1)$. Such attempts to build links were focused vertically as well as horizontally eg between local people and local governmental policy makers: "what we tried to do is create a situation whereby community relations between the state and the communities could be built, but also bridges between sub-communities" (B2). Others were trying to promote awareness of democracy and political culture through organised visits to places such as the Houses of Parliament or through more informal activities intended to encourage respectful debate and listening.

\section{Funding}

At the time of the survey, $89 \%$ of BBAs (112) reported being in receipt of some kind of external financial resources or in-kind external support. We used a multiple response question to gauge the range of sources. The most frequently reported source of funding was charitable trusts ( $45 \%$ of all BBAs surveyed) followed by grants or contracts from central government or the European Union (28\% of all BBAs) and grants or contracts from local government (27\% of all BBAs). A total of 49 respondents $(39 \%)$ reported that their BBA received no funding from any governmental source. Only $9 \%$ of BBAs were receiving donations from individuals although 19\% were receiving support in the form of paid staff time donated by another third sector organisation and $17 \%$ were similarly benefiting from the involvement of volunteers attached to another organisation. The fact that charitable trusts were more frequent funding sources for BBAs than governmental 
organisations seemed to be attributable to the reluctance of governmental authorities to fund activities which they perceived as risky, contentious or in competition with their own bridging efforts; even though the development of 'community cohesion' has been a longstanding public policy aim in the UK for several years.

The case studies suggested that the financial situation of BBAs can be extremely precarious. Project funding was often insufficient to cover real costs, although some study participants said that they had been able to access substantial funding after initial self-funded pilot projects had demonstrated success. BBAs often survived by drawing together resources 'begged' from a range of goodwill sources and by quietly crosssubsidizing activities. Some BBAs, particularly those which bridged faith groupings or were attached to religious congregations, were able to attract one-off small financial donations or donations in kind: a "lot of the community is fairly economically disadvantaged, it is nevertheless still rich in its charitable spirit..." (T1). Other BBAs benefited from the involvement of volunteers with specialist fundraising expertise: "I have an awareness of local regeneration funding so will advise on funding and support and the development of funding proposals" (B2).

\section{Organisational Structure}

Seventy per cent of BBAs interviewed at Stage Two described themselves as being part of a broader organisation; generally a 'project' of that organisation. A further $11 \%$ were part of an organisational consortium and only $19 \%$ declared themselves to be independent third sector organisations, usually a registered charity. On the other hand, nearly half $(49 \%)$ were formally part of a registered charity. Case studies suggested that smaller BBAs tended to have relatively informal relationships with larger, more formal organisations that were able to provide access to infrastructural support and other resources. For example, a small inter-faith project was organisationally tightly intertwined with both the local primary school, where one of the leaders was an employee, and with a local church of which a co-leader was a member. The resources of several local churches in terms of support from clergy, paid staff, volunteers, and meeting spaces, was crucial to the organisational sustainability of another case BBA - even though that BBA did not have specifically interfaith aims and declared itself to be focused broadly on bringing together local people from different backgrounds.

As might be expected given the local nature of the BBAs we studied, most were heavily or totally dependent on volunteers. Fifty eight percent of respondents said that their BBA had some paid staff and $31 \%$ were totally run by volunteers. Study participants at Stage Three felt that only volunteers could have real credibility in bridge-building at a local level: "You have to have it in your heart - not think about what it will pay or what you will get out of it... You have to have a positive belief in helping your fellow human beings" (B1). However, some of the smaller BBAs expressed a desire to move away from their dependence on volunteers and wished to recruit paid staff, believing that this would make them more sustainable and consistent: "the project has started and run out of steam so many times" (T1).

In addition to their high dependence on volunteers, we found the BBAs studied to be generally dependent on just one or two key people (paid or unpaid) with roots in the local area, a commitment to bridge-building and sufficient enthusiasm to sustain others through the peaks and troughs of organisational life; not only funding difficulties but also difficulties of attracting local support. A typical comment was: "he is a pillar, without him 
the whole thing would collapse" (T1).

A positive aspect of this dependence on just one or two leaders was the trust engendered by their visible long-term commitment. For example, a leader of an interfaith BBA, herself a Muslim, was able to encourage Muslim women to visit the places of worship of other religions; she assured them: "come with me and I will not let you do anything you don't like to do" (B1). A more negative aspect of this dependence on one or two leaders is the challenge it presents for succession by discouraging new people from coming forward to take responsibility.

\section{Challenges faced by Local BBAs}

At Stage Three of the study we were able to obtain qualitative data about the challenges faced by local BBAs; some of which were broadly 'organisational' challenges and others of which were more about the challenges of 'bridge-building' itself.

\section{$\underline{\text { Organisational Challenges }}$}

Heavy dependence on volunteers was generally seen as a positive feature by study participants; it gave their activities credibility and legitimacy as authentically local endeavours: "community cohesion happens most naturally when it's led by people in those communities and it's not brought to them" $(\mathrm{O} 1)$. At the same time, there were challenges entailed in high volunteer involvement and some study participants were keen to recruit at least some paid staff as they felt the latter could ensure more continuity, efficiency and consistency in activities. Reliance on volunteers could also mean that BBAs were lacking needed expertise, such as fundraising or networking skills, or experience of navigating local governmental procedures: "You need external grants and somebody who knows how to get them" (B1). Heavy dependence on volunteers combined with heavy dependence on just one or two leaders raised issues in many BBAs about their longer term sustainability: "in the end, personalities are important. If you don't have the right people at the helm, the best case scenario is that there will not be progress. In the worst case scenario, things will simply fall apart" (T1).

The nature of the organisational status of BBAs could also present both advantages and challenges. Whereas close association with a larger or more formal organisation was often very beneficial to local BBAs in terms of providing crucibles for start-ups and opportunities for sharing resources and infrastructure, it could also lead to confusion about governance and accountability for activities. For example, one BBA was essentially a project of a larger voluntary organisation but it had its own steering group; we were told that the steering group had initially been "set up without any clear idea of what it was supposed to do or why it was needed" (B2). Although such ambiguity was generally tolerated on a day to day basis, it could prove problematic when dealing with funders who were uneasy about supporting activities when lines of accountability were unclear. It could also mean that whereas there was enthusiastic participation in operational activities and events, more strategic discussions were not seen as the responsibility of any particular grouping. One case BBA was only able to get attendance at constitutionally essential membership meetings by eliding such meetings with popular social events.

Questions about accountability were not the only obstacle to fund-raising by BBAs. Another obstacle frequently mentioned was the complexity of application processes 
prescribed by potential funders, both governmental agencies and charitable trusts. It was thought that application processes: "should be simplified. The very people that need the money are losing out because they can't fill in the forms" (T3).

The need to categorise precisely - both target groupings and activities - was also a major problem to BBAs which often did not see themselves as dealing with precise categories of people or carrying out neatly delineated services. It was felt that the idea of putting people into categories runs counter to the whole vision of developing integrated and cohesive communities: "They want community cohesion but they put everybody into a [separate] box" (B1). Nor were BBAs necessarily able to spend money received within the short time scales prescribed. In one case, £3k funding had been clawed back from a $£ 5 \mathrm{k}$ grant because it had not been spent within the specified period: "there is the challenge of reconciling external formal frameworks, eg funding timescales, with the reality of community work" $(\mathrm{O} 2)$.

In addition, the governmental emphasis on measurable project outputs and impact was seen as especially problematic in relation to bridge-building activities: "it's very hard to measure an event of this type and we wrestle with this every year." (T3). In short, governmental funding was generally not seen as attractive for BBAs: "they don't cover costs and they're not really about enabling [the BBA] to deliver its mission, there are too many constraints" (B2).

\section{Bridge-Building Challenges}

Although many of the challenges encountered in the nine case BBAs were organisational and not untypical of other small community groups (Smith, 2000), many challenges could be seen to be directly linked to the nature of the activities and objectives of the BBAs. For example, a key challenge was simply to fulfil the aims of the BBA and to reach out widely to local people: "we are preaching to the converted. We need to reach those who are still not convinced" $(\mathrm{O} 1)$. In some areas there was an embedded history of antagonism to immigrants and minorities which was being passed from one generation to another. In such a climate, those who involved themselves in bridge-building activities could be ostracised by their own community: "it's difficult to stand out as different in a community as tightly knit as this one...because you put yourself at risk and in the position of the person being attacked" $(\mathrm{O} 1)$.

We also found examples of local cynicism about bridge-building as a result of the numerous projects and consultations which had taken place in the past but which had not led to noticeable improvements in cross-group relationships. The legitimacy of bridge-building projects could also be questioned if they appeared to be partial: "we are perceived by black and minority ethnic (BME) communities as white middle class and by the white communities as an organisation that only supports BME communities" (B2).

The case studies also revealed numerous examples of practical barriers to bridging activities which arose from the very cultural and faith differences that BBAs were wishing to address. For example, a project intended to bring together people attending two luncheon clubs - one attended mainly by older Bangladeshi men and the other attended by white men and women - was struggling because of the reluctance of the Bangladeshi men to socialise with women or take meals with them. Conversely, an interfaith (Christian and Muslim) women's group was flourishing because it provided women-only activities which allowed the Muslim women to participate in social activities without any 
embarrassment.

It was clear that successful bridge-building was dependent not only on mutual respect but also quite sophisticated understanding of customs and sensibilities and a willingness to ignore points of contention. One Christian participant in an interfaith BBA said about working with Muslims said: "Two faith groups working together is complex and multilayered. Some of the layers - like we believe in God and we value prayer - work well together, and other layers like what is our moral stance on homosexuality never worked well together. We never talk about that" (T1)

Study participants from BBAs which targeted refugees and asylum seekers and older people suggested that there were certain characteristics of these groups that made bridge building especially difficult. They faced immigration, language, finance and trust issues which affected their ability to engage with bridging initiatives. Age was also identified as a barrier: "bridge building is really challenging because the people are older... If you gave them the choice, they'd probably say no. So you have to coax them" (T2). Another study participant suggested that the combination of age and inability to speak English created particular barriers. Such people "have not got the skills necessary which would enable them to walk across any bridges we might build ... some white communities haven't got the skills either" $(\mathrm{O} 1)$. It was suggested that even young people brought up in England can lack the skills necessary to operate in a multi-cultural environment, especially when they have grown up in mono-cultural areas and attended mono-cultural schools.

Features of the broader social, economic and political environment were also identified as challenges to local-level bridge-building. Poverty and deprivation and competition for scarce public resources set groups against each other: "you have two poor communities fighting to get out of the same heaps and they are scrambling over each other" (01). Residential segregation at the local level was another obstacle: "we don't have Asian families living here. The Asian families that have tried to move in were fire bombed." (O1).

Some study participants felt that bridge-building efforts did not get the support they needed from local politicians: "[local councillor] is not too keen to speak openly because he feels he will lose votes. They should be more keen to stand up and say this is a model that works" (T1). Others felt that sensationalist reporting in the mass media tended to exacerbate tensions between communities: "they like to report on the rubbish but not so much on the good" (O3).

\section{Discussion}

\section{BBAs and the Broader Third Sector}

The starting point for this study was our wish to fill a gap in knowledge about an unexplored segment of the third sector. In this section, then, we consider our study findings in the context of the existing broader body of knowledge about the third sector.

Although our study was focused on a specialist segment of the third sector defined by aim and geographical location - local groups with the explicit aim of building bridges across the boundaries of faith and/or ethnicity - many of our findings about the organisational features and challenges of BBAs reflect earlier studies about the third 
sector generally; for example, about the way in which third sector organisations are often formed by people keen to respond to a perceived social need, perhaps just one or two enthusiastic and entrepreneurial individuals (Harris, 1994 ;Young, 1991). Similarly, the organisational challenges posed by heavy dependence on volunteers in the third sector have been noted earlier. The multiple benefits which can flow from volunteers' gifts of time, their enthusiasm for the cause and their closeness to local communities can go hand-in-hand with threats to service continuity and organisational sustainability (Netting et al, 2004; Ockenden, 2007).

Again, many of our findings about the features of BBAs reflect findings about the community and grassoots groups (Smith, 2000). Writers have noted, for example, the ambiguous organisational and governance structures and processes which tend to characterise small and informal third sector groupings, as well as the way in which such groups can be isolated from other similar groups and so miss out on opportunities to share experiences and strengthen their organisations (Rochester et al, 1999; Home Office, 2004).

Although there is continuing debate about the extent to which the third sector is in practice as innovative, flexible and responsive to new and emergent needs as some policy makers suggest (Kramer, 2000; Kendall, 2003), our own findings do tend to confirm the third sector stereotype. The overwhelming majority of BBAs in our study could be seen as constituting an explicit response to an increasingly diverse society, since $95 \%$ were focused on social cohesion, social interaction and/or mutual understanding across identity group boundaries. We also found a very wide variety of activities promoted by the study BBAs. There was some indication that activities were planned in response to availability of funding (eg for 'educational' events) but it was also clear that planning of BBAs' activities were guided by local experience of 'what works'. Traditional ideas and recommended procedures about facilitated dialogue, conflict resolution and even cultural and faith sensitivity, were often eschewed in favour of activities which community leaders thought would be 'fun' or would at least get people of diverse backgrounds interacting socially within a single space.

At the same time as our study findings reflected earlier suggestions that third sector organisations share distinctive (but not necessarily unique) features (Harris et al, 2001), they also surfaced features which have been less observed in earlier studies of third sector organisations. One interesting finding, for example, was the close links - formal and informal - between BBAs and other organisations, often charities and other larger third sector organisations, which acted as crucibles for the start-up and later development of BBAs, providing the shelter of their formal legal status and the free use of resources such as rooms, equipment and office services. Future research could perhaps explore whether this phenomenon is prevalent in practice in other parts of the third sector or whether it is directly related to the nature of local BBA activity such as the sensitivity of their aims and activities, their smallness and absence of governmental funding. Such research could also explore whether these kinds of links are instrumental in enabling organisationally fragile groupings like local BBAs to persist once set up, as such a finding would point to the possible utility of developing networking and infrastructure support for small BBAs.

We also noted the key role in the funding of BBAs played by charitable trusts, rather than governmental or individual sources. This suggests that trusts are still, in this field at least, playing the role of supporting new and 'risky' third sector ventures which cannot, or 
do not wish to, obtain funding from governmental sources or from appeals to the general public (Daly, 2008). Again, further research questions are raised by this finding. For example, what features of BBAs make them especially attractive to charitable funders and to what extent is the found pattern of funding a reflection of special features of BBAs? Are there lessons here for other third sector organisations which aspire to attract charitable trust funding?

\section{Policy Implementation and the Strengthening of Civil Society}

In this closing section of the paper we consider briefly some implications of our findings for the potential contribution of BBAs to public policy implementation and the strengthening of civil society. These are matters which we have considered in depth elsewhere (Harris and Young, 2009b) so here we confine ourselves to drawing on our study findings to raise briefly some questions about the current expectations on BBAs in the UK (outlined at the start of this paper) to contribute to building social cohesion and a tolerant civil society.

The findings can be seen as confirming that, in many respects, the third sector is fulfilling its expected policy role. Through BBAs, the sector is apparently responding positively to the new challenges arising from the changing demography of faith, ethnicity and country of origin in the UK and the policy drive to build linkages between people of diverse backgrounds. At the local level numerous small organisations and groupings have emerged, each trying to build bridges across identity group boundaries and doing so in a wide variety of ways. Moreover the groups are firmly rooted in their immediate localities and are led by people who are keen to respond proactively to special features of their local environment. The data on year of founding suggests that a high proportion of bridge-building initiatives have been able to survive for at least five years.

All the same, the data also suggest that caution should be exercised about the potential of local BBAs to contribute in a substantial way to building social cohesion and tolerant societies. For it seems that the capacity of BBAs to expand their existing activities and still be effective in bridge-building at a local level is limited.

Most of the BBAs we found are small, informal and organisationally vulnerable. They are often highly dependent on volunteers and just one or two committed leaders with backgrounds which make them especially skilled at building bridges. Many BBAs struggle to extend their reach beyond a core group. They sustain themselves by drawing heavily on the support of larger or more formal, organisations. They have little or no funding from governmental sources; and they choose their activities according to what they think will 'work' locally rather than according to guidelines for dialogue, conflict resolution and reconciliation recommended by faith and equality infrastructure bodies and assumed in public policy documents. Nor do they necessarily see themselves as responding to clear categories of people defined according to 'faith' or 'ethnic group'. They often see themselves as 'just building bridges' between people who are different but the differences may be due to combinations of characteristics which are not easily pigeon-holed.

Our data suggest that it is these very features of smallness, informality and organisational vulnerability which are closely linked to the ability of BBAs to continue their local bridge-building efforts. They are able to 'muddle through' precisely because they are small scale and not bound by regulations, official categorisations or close 
monitoring and accountability procedures. Thus larger scale funding for expansion (which in terms of these BBAs could be in the region of just $£ 5,000$ ) presents BBAs with major challenges around making applications, accounting for money received and generally living up to external expectations.

Although the data suggest that BBAs have limited potential to expand their role without losing their ability to continue their existing community activities, the description and analysis in this paper of their current activities do provide some ideas about the sustainability and expansion of bridge-building activities in the future. For example, it suggests that relatively low levels of external funding from governmental sources would be welcomed if they could be used to support locally chosen activities (which might well be purely social), were free of onerous application and evaluation processes, and did not force groups to compete or to describe their participants as belonging to sharply defined categories.

The study also suggests that sensitive and positive gestures of support from third sector infrastructure bodies, from local media and politicians (and even perhaps researchers working in a collaborative fashion) could be key factors in encouraging BBAs to continue their efforts to respond to the growing diversity of local populations. For it is clear from the findings that those who lead and participate in bridging activities need commitment and courage to continue in the face of local opposition - not only from extremist political groups but also, sometimes, from their own family and friends. 


\section{Endnotes}

(1) The bridging metaphor is a key part of social capital theory and we have explored the relevance of 'bridging social capital' to our own BBA study in Harris and Young, 2009b. In the BBA study we used the term 'bridge-building' to refer to organised activities which reflect the public policy goal (CIC, 2007) of increasing inter-personal relationships between people of different faiths, ethnicity and country of origin and encouraging them to work together to develop shared values and achieve common goals. For the empirical phase of our study we sought out BBAs which had an explicit aim of 'bridge-building'.

(2) The term 'facilitated dialogue' is widely used in inter-faith and conciliation literature and we used it in our study as a category to include activities in which structured conversations were organised and supported by one or more external facilitators.

\section{Acknowledgements}

The authors are grateful for the assistance of Jane Andrews Ph.D; Chung-Dao Pan, Ph.D. and Selena Teeling in preparing this paper. They also acknowledge careful and helpful comments from the journal Editor and three anonymous reviewers.

\section{References}

Allen, J., and Cars, G. (2001). Multiculturalism and Governing Neighbourhoods. Urban Studies 38 (12): 2195-2209.

Allport, G. W. (1954). The Nature of Prejudice. MA, Addison-Wesley.

Amin, A. (2002). Ethnicity and the Multicultural City: Living with Diversity. Environment and Planning 34 (6): 959-980.

Barekh, P. (2000). The Future of Multi-Ethnic Britain. Report of the Commission on the Future of Multi-Ethnic Britain. London: Runnnymede Trust \& Profile Books

Bryman, A. (2001) Social Research Methods Oxford: Oxford University Press

Cabinet Office (2008) £130m Grassroots Grants scheme opens its doors to small local voluntary and community groups Cabinet Office Press Release_4 September 2008 www. www.cabinetoffice.gov.uk/third_sector/news

Cairns, B., Carroll, M. and Harris, M. (2007) Action Research: Professional Researchers in the Community in Cnaan, R. and Milofsky, C. (eds) Handbook of Community Movements and Local Organizations New York: Springer

Cantle, T. (2001) Community Cohesion: A Report of the Independent Review Team London: Home Office 
CIC (2007) Our Shared Future London: Commission on Integration and Cohesion

Daley, C. (2009) Exploring Community Connections: Community Cohesion and Refugee Integration at a Local Level Community Development Journal 44(2) 158-171

Daley, S. (2008) Institutional Innovation in Philanthropy: Community Foundations in the UK Voluntas 19 (3) 219-241

DCLG (2006). Strong and Prosperous Communities. London: Department for Communities and Local Government

Dench, G., Gavron, K., and Young, M. (2006). The New East End: Kinship, Race and Conflict London: Profile Books

Denham, J. (2002). Building Cohesive Communities: A Report of the Ministerial Group on Public Order and Community Cohesion. London: Home Office.

Eisenhardt, K. (1989) Building Theories from Case Study Research Academy of Management Review 14 (4) 532-550

Faulkner, D. (2004). Civil Renewal, Diversity and Social Capital in a Multi-ethnic Britain. Runnymede Perspectives. London, Runnymede

Flint, J. and Robinson, D. (2008) Conclusions in Flint, J. and Robinson, D. (eds) Community Cohesion in Crisis? New Dimensions of Diversity and Difference Bristol, Policy Press

Forrest, R., and Kearns, A. (2001).Social Cohesion, Social Capital and the Neighbourhood. Urban Studies 38 (12): 2145-2162.

Furbey, R., Dinham, A., Farnell, R., Finneron, D. and Wilkinson, G. (2006) Faith as Social Capital? Connecting or Dividing? Bristol: Policy Press

Gilchrist, A. (2004). Community Cohesion and Community Development. Bridges or Barricades, London: Community Development Foundation \& Runnymede Trust

Harris, M. (1994) The Power of Boards in Service-Providing Agencies: Three Models Administration in Social Work 18 (2) 1-15

Harris, M., Rochester, C. and Halfpenny.P (2001) Voluntary Organisations and Social Policy: Twenty Years of Change in Harris, M. and Rochester, C. Voluntary Organisations and Social Policy in Britain Basingstoke: Palgrave

Harris, M. and Young, P. (2009a) Bridging Community Divides: The Impact of Grassroots Bridge Building Activities London: Institute for Voluntary Action Research (IVAR)

Harris, M. and Young, P. (2009b) Developing community and social cohesion through grassroots bridge-building: an exploration', Policy \& Politics, 37(4) 517-534

Home Office (2004) Building Civil Renewal: Government Support for Community 
Capacity Building and Proposals for Change London: Home Office

Jeong, H., and Lerche, C. (1999).'Research on Conflict Resolution. In Jeong, H. (Ed) Conflict Resolution: Dynamics, Process and Structure. Aldershot: Ashgate.

Kendall, J. (2003) The Voluntary Sector London: Routledge

Kramer, R.M. (2000) A Third Sector in the Third Millenium? Voluntas 11 (1) 1-23

Malek, B. (2008) Rethinking Segregation in Davison, S. and Rutherford, J. Race, Identity and Belonging London: Lawrence and Wishart

Milligan, C. and Fyfe, N. (2004) Putting the Voluntary Sector in its Place: Goegraphical Perspectives on Voluntary Activity and Social Welfare in Glasgow Journal of Social Policy_33 (1) 73-94

Modood, T. (2007). Multiculturalism: A Civic Idea. Cambridge: Polity Press.

Netting, F.E., Nelson, H.W., Borders, K., Huber, R. (2004) Volunteer and Paid Staff Relationships: Implications for Social Work Administration Administration in Social Work 28 (3) $69-89$

Ockenden, N. (ed) (2007) Volunteering Works: Volunteering and social policy, The Commission on the Future of Volunteering: London

Pennant, R. (2005) Diversity, Trust and Community Participation in England London: Home Office

Putnam, R. D. (2007). E Pluribus Unum: Diversity \& Community in the Twenty-first Century Scandinavian Political Studies 30 (2): 137-174.

Rochester, C., Harris, J. and Hutchison, R. (1999) Building the Capacity of Small Voluntary Agencies Final Report London: Centre for Voluntary Organisation, LSE

Smith, D.H. (2000) Grassroots Associations Thousand Oaks, Ca: Sage

Weller, P. (2009) How Participation Changes Things: 'Interfaith', 'Multifaith' and a New Public Imaginary in Dinham, A., Furbey, R. and Lowndes, V. (eds) Faith in the Public Realm: Controversies, Policies and Practices Bristol: Policy Press

Young, K. (1991) Meeting the Needs of Strangers: Voluntary Action in a Changing World London: Gresham College 
Table One - Stage Three Case Studies

\begin{tabular}{|c|c|c|c|c|c|c|}
\hline Notation/Area & Groups Targeted & Area Covered & Organisation Status & Run By & Funding & BBA Approach \\
\hline \multicolumn{7}{|l|}{ Birmingham } \\
\hline B 1 & $\begin{array}{l}\text { Moslem women from } \\
\text { Pakistani and } \\
\text { Somali background } \\
\text { and white Christian } \\
\text { women }\end{array}$ & neighbourhood & $\begin{array}{l}\text { independent } \\
\text { association }\end{array}$ & $\begin{array}{l}\text { volunteers } \\
\text { only }\end{array}$ & $\begin{array}{l}\text { small amounts of } \\
\text { foundation funding }\end{array}$ & $\begin{array}{l}\text { facilitated dialogue } \\
\text { faith activities } \\
\text { education } \\
\text { social events }\end{array}$ \\
\hline B 2 & $\begin{array}{l}\text { faith and ethnic } \\
\text { groups and people } \\
\text { from different } \\
\text { countries }\end{array}$ & $\begin{array}{l}\text { several } \\
\text { contiguous } \\
\text { neighbourhoods }\end{array}$ & $\begin{array}{l}\text { partnership of lead } \\
\text { formal charity with } \\
\text { multiple community } \\
\text { groups }\end{array}$ & $\begin{array}{l}\text { paid staff of } \\
\text { lead agency } \\
\text { and } \\
\text { volunteers }\end{array}$ & national government & $\begin{array}{l}\text { facilitated dialogue } \\
\text { facilitated conflict } \\
\text { resolution }\end{array}$ \\
\hline B 3 & $\begin{array}{l}\text { refugees and } \\
\text { asylum- seekers } \\
\text { from African region }\end{array}$ & region & registered charity & volunteers & $\begin{array}{l}\text { originally } \\
\text { government project } \\
\text { funds but now } \\
\text { fundraising for } \\
\text { donations }\end{array}$ & $\begin{array}{l}\text { social events } \\
\text { education/training } \\
\text { facilitated dialogue } \\
\text { advice and others }\end{array}$ \\
\hline \multicolumn{7}{|l|}{ Oldham } \\
\hline 01 & $\begin{array}{l}\text { all minority ethnic } \\
\text { groups and white } \\
\text { population }\end{array}$ & borough & $\begin{array}{l}\text { project of a formal } \\
\text { third sector } \\
\text { organisation }\end{array}$ & volunteers & $\begin{array}{l}\text { governmental } \\
\text { project funding }\end{array}$ & $\begin{array}{l}\text { theatre-based } \\
\text { facilitated dialogue }\end{array}$ \\
\hline 02 & $\begin{array}{l}\text { Asian and white } \\
\text { groups particularly } \\
\text { the young and the } \\
\text { elderly }\end{array}$ & $\begin{array}{l}\text { two adjacent } \\
\text { mono- cultural } \\
\text { neighbourhoods }\end{array}$ & $\begin{array}{l}\text { partnership of lead } \\
\text { formal charity with } \\
\text { several smaller }\end{array}$ & $\begin{array}{l}\text { paid staff of } \\
\text { lead agency } \\
\text { and } \\
\text { volunteers }\end{array}$ & $\begin{array}{l}\text { foundations } \\
\text { businesses }\end{array}$ & $\begin{array}{l}\text { service delivery } \\
\text { dialogue } \\
\text { social activities }\end{array}$ \\
\hline
\end{tabular}


Asian and white boys and young men borough project of voluntary

sector sports

organisation small amounts of foundation funds and dues from

participants sporting activities 


\begin{tabular}{|c|c|c|c|c|c|c|}
\hline Notation/Area & Groups Targetted & Area Covered & Organisation Status & Run By & Funding & BBA Approach \\
\hline \multicolumn{7}{|l|}{ Tower Hamlets } \\
\hline Tuver Tramicto & $\begin{array}{l}\text { local Moslem and } \\
\text { Christian groups }\end{array}$ & neghbourhood & $\begin{array}{l}\text { joint project of a } \\
\text { church and a local } \\
\text { Moslem group }\end{array}$ & $\begin{array}{l}\text { volunteers } \\
\text { with support } \\
\text { from church } \\
\text { clergy }\end{array}$ & $\begin{array}{l}\text { fundraising for } \\
\text { donations and } \\
\text { governmental }\end{array}$ & $\begin{array}{l}\text { planning shared } \\
\text { worship } \\
\text { accommodation } \\
\text { social activities } \\
\text { faith activities } \\
\text { service provision }\end{array}$ \\
\hline T 2 & $\begin{array}{l}\text { white elders and } \\
\text { Bengali elders }\end{array}$ & borough & $\begin{array}{l}\text { project of a formal } \\
\text { third sector welfare } \\
\text { organisation }\end{array}$ & paid staff & $\begin{array}{l}\text { central and local } \\
\text { govt foundation } \\
\text { funds }\end{array}$ & $\begin{array}{l}\text { service delivery } \\
\text { dialogue } \\
\text { social events }\end{array}$ \\
\hline T 3 & $\begin{array}{l}\text { all ethnic and faith } \\
\text { groups living in the } \\
\text { area }\end{array}$ & neighbourhood & $\begin{array}{l}\text { project of local } \\
\text { churches }\end{array}$ & $\begin{array}{l}\text { one part-time } \\
\text { community } \\
\text { worker and } \\
\text { volunteers }\end{array}$ & $\begin{array}{l}\text { central and local } \\
\text { govt } \\
\text { foundation funds } \\
\text { businesses }\end{array}$ & $\begin{array}{l}\text { annual social } \\
\text { event/festival }\end{array}$ \\
\hline
\end{tabular}


Table Two - Identity Groups Involved in BBAs

\begin{tabular}{lll}
\hline & Frequency & Percent \\
\hline Mainly inter-ethnic & 58 & 45.7 \\
Mainly inter-faith & 20 & 15.7 \\
Generally bridge building & 20 & 15.7 \\
Between people from different countries of origin & 12 & 9.4 \\
Inter-ethnic, inter-faith \& between people from & 10 & 7.9 \\
different countries & & \\
Inter-ethnic \& inter-faith & 4 & 3.1 \\
Inter-ethnic and between people from different coun. & 3 & 2.4 \\
\hline Total & 127 & 100.0 \\
\hline
\end{tabular}

Table Three - Bridge Building Activities (multiple-response question)

\begin{tabular}{llll}
\hline & Count & $\begin{array}{l}\text { Pct } \\
\text { responses }\end{array}$ & $\begin{array}{l}\text { Pct } \\
\text { cases }\end{array}$ \\
\hline Social activities & 103 & 19.9 & 81.1 \\
Education/training/learning/childcare & 92 & 17.8 & 72.4 \\
Facilitated dialogue & 81 & 15.7 & 63.8 \\
Sport & 52 & 10.1 & 41.0 \\
Visual arts & 50 & 9.7 & 39.4 \\
Religious/faith-based & 40 & 7.7 & 31.5 \\
Facilitated conflict resolution & 29 & 5.6 & 22.8 \\
Renewal/repair/regeneration of physical fabric & 22 & 4.3 & 17.3 \\
Other & 48 & 9.3 & 37.8 \\
\hline Total & 517 & 100.0 & \\
\hline
\end{tabular}

